\title{
Effect of body size heterogeneity on the aggressive behavior of larvae of matrinxã, Brycon amazonicus (Characiformes, Bryconidae)
}

Thaís Billalba CARVALHO ${ }^{1,2 *}$, Ellen Cristina Monteiro de SOUZA ${ }^{1}$, Jaquelinne PINHEIRO-DA-SILVA ${ }^{3}$, Marle Angélica VILLACORTA-CORREA ${ }^{4}$

\author{
Universidade Nilton Lins, Manaus-AM, Brasil \\ 2 Universidade Federal do Amazonas (UFAM), Instituto de Ciências Biológicas (ICB), Manaus-AM, Brasil \\ 3 Universidade Federal do Rio Grande do Norte, Natal-RN, Brasil \\ ${ }^{4}$ Universidade Federal do Amazonas (UFAM), Faculdade de Ciências Agrárias (FCA), Manaus-AM, Brasil \\ * Corresponding author: thaisbillalba@ufam.edu.br
}

\begin{abstract}
Brycon amazonicus is a native Amazonian fish that is important for aquaculture in South America. Larval mortality is high in this species in intensive breeding systems due to aggressiveness among larvae. The present study investigated experimentally the effects of body size heterogeneity on the aggressive behavior and survival of B. amazonicus during the early stages of larval development. Two treatments (larvae groups with homogeneous and heterogeneous body size) were evaluated throughout early larval stages tested at six time points: 12, 24, 36, 48, 60 and 72 hours after hatching (HAH). Two experiments quantified, respectively, aggressive interactions and mortality rates among larvae at each time point. The frequency of aggressive interactions exhibited by the less aggressive larvae in each replicate was higher in the homogeneous size treatment. Aggressiveness was higher at $12 \mathrm{HAH}$, decreasing thereafter, and increasing again at $72 \mathrm{HAH}$. The mortality rate significantly increased with the larval stage, and was higher in the homogeneous than in the heterogeneous sized groups. Our results showed that aggressiveness in $B$. amazonicus larvae is affected by size variability and larval development stage. This knowledge about larval behavior is important to develop measures to improve larval health and survival in intensive production systems for this species.
\end{abstract}

KEYWORDS: aggressiveness, fish, larviculture, mortality

\section{Efeito da heterogeneidade no tamanho corporal sobre o comportamento agressivo de larvas de matrinxã, Brycon amazonicus (Characiformes, Bryconidae)}

\section{RESUMO}

Brycon amazonicus é um peixe nativo da Amazônia que apresenta importância para a aquicultura na América do Sul. Em sistemas de criação intensiva, a mortalidade é alta nessa espécie devido à agressividade entre as larvas. O objetivo deste estudo foi testar se o tamanho diferencial entre indivíduos afeta o comportamento agressivo e a sobrevivência de $B$. amazonicus durante os estágios iniciais do desenvolvimento larval. Dois tratamentos (grupos de larvas com tamanho homogêneo e heterogêneo) foram avaliados ao longo do desenvolvimento larval em seis pontos de observação: 12, 24, 36, 48, 60 e 72 horas pós-eclosấo (HPE). Em dois experimentos foram quantificadas, respectivamente, as interaçóes agressivas e a mortalidade em cada ponto de observaçáo. A frequência das interaçóes agressivas exibidas pelas larvas menos agressivas foi maior no tratamento de tamanho homogêneo. A agressividade também foi maior às $12 \mathrm{HPE}$, diminuiu nos períodos intermediários e aumentou novamente às $72 \mathrm{HPE}$. A taxa de mortalidade aumentou ao longo dos estágios larvais, sendo observada maior mortalidade total nos grupos de tamanho homogêneo. Os resultados deste estudo indicam que a agressividade em $B$. amazonicus é modulada pela variação do tamanho dos indivíduos e pelo estágio de desenvolvimento das larvas. O conhecimento sobre o comportamento de larvas é importante para desenvolver medidas que melhorem a saúde e a sobrevivência em sistemas de produção intensiva para esta espécie.

PALAVRAS-CHAVE: agressividade, peixe, larvicultura, mortalidade

CITE AS: Carvalho, T.B.; Souza, E.C.M. de; Pinheiro-da-Silva, J.; Villacorta-Correa. 2018. Effect of body size heterogeneity on the aggressive behavior of larvae of matrinxã, Brycon amazonicus (Characiformes, Bryconidae). Acta Amazonica 48: 304-310. 


\section{INTRODUCTION}

Size heterogeneity is considered one of the central problems in aquaculture, especially in predatory fish species (Kestemont et al. 2003). The consequences of size variation during the initial stage of development (larval stage) are usually more drastic than in the adult stage, as larval size variation favors aggressiveness and mortality (Baras 1998). Furthermore, heterogeneous size distributions often determine social dominance, which is defined by interactions between individuals; larger animals are usually dominant, while smaller animals are subordinate (Huntingford and Turner 1987). The establishment and maintenance of this dominance hierarchy trigger a potentially stressful situation in which dominant individuals may show less social stress than subordinates (Fernandes and Volpato 1993). In this context, individual size variation within a group may directly affect the display of aggressive behavior in fish.

Homogeneously sized groups tend to be more aggressive, as the animals have similar sizes and thus possess similar fighting abilities (Beeching 1992). However, some studies suggest that heterogeneous groups are more aggressive, as the display of the agonistic interaction is directly modulated by the size variation between cospecifics. In flounder (Paralichthys olivaceus) and hybrid catfish (Silurus meridionalis-asotus) the intensity of aggressive interactions is determined by differences in fish size (Dou et al. 2000; Yang et al. 2015).

Brycon amazonicus (Spix and Agassiz 1829), known in Brazil as matrinxã, is a fish native to the Amazon basin and is of great commercial interest, being successful in breeding systems in Brazil and other South American countries (ZaniboniFilho et al. 2006). It is the second most produced species in Northern Brazil, due to its fast growth, good acceptance of artificial feed and high-quality meat (Gomes and Urbinati 2010). Aggressive behavior in this species is exacerbated in intensive production systems by the confinement and high density of individuals (especially during the larval stage), resulting in high mortality rates (e.g. Senhorini et al. 1998; Souza et al. 2014). Aggressive behavior can be specially limiting in intensive breeding systems, where matrinxã larvae loss can be as high as $90 \%$ due to injuries and cannibalism, posing substantial technological difficulties for hatching management (Senhorini et al. 2002). It is not clear, however, whether fish body size heterogeneity actually modulates aggressiveness in this species.

Our aim was to evaluate the influence of size heterogeneity on the aggressiveness and mortality of $B$. amazonicus larvae. We hypothesized that aggressive behavior among larvae increases with size variation within the cohort, and consequently increases the mortality rate.

\section{MATERIAL AND METHODS}

This study was performed in accordance with the ethical principles in animal experimentation adopted by the Brazilian National Council of Animal Experimentation Control (Conselho Nacional de Controle de Experimentação Animal - CONCEA) and was approved by the Ethics Committee on Animal Use (Comissão de Ética no Uso de Animais - CEUA) of UFAM, Manaus, AM (protocol no. 035/2011).

\section{Experiment I}

This experiment was conducted at the Aquaculture Station of the Experimental Farm of the Federal University of Amazonas (Universidade Federal do Amazonas - UFAM), located in Manaus, Amazonas (AM), Brazil (02 38 $56.1^{\prime}$ 'S; $\left.60^{\circ} 03^{\prime} 14.7^{\prime \prime} \mathrm{W}\right)$. The larvae were produced via artificial propagation using the crude extract of the carp pituitary gland as described by Romagosa et al. (2001). After extrusion, the fertilized eggs were incubated at a density of $1 \mathrm{~g}$ of eggs $\mathrm{L}^{-1}$ of water $\left(\sim 1\right.$ larvae $\left.\mathrm{mL}^{-1}\right)$ in four incubators $(35 \mathrm{~L})$ connected to a freshwater renewing system. The water quality was maintained at $26.9 \pm 0.5^{\circ} \mathrm{C}$ and $\mathrm{pH} 7.45 \pm 0.6$. Fertilization $(93 \%)$ and hatching $(88.7 \%)$ rates were estimated according to Romagosa et al. (2001). The point when $50 \%$ of the larvae had hatched was considered as time zero (Romagosa et al. 2001). After hatching, the animals were fed to satiation with live plankton up to 36 hours after hatching (HAH) or with an inert commercial powdered feed (Purina 55- with 40\% crude protein) after this period.

To evaluate the effect of size heterogeneity on the aggressive behavior of matrinxã larvae we established two treatment conditions: groups of homogeneous body size (with three individuals of similar length), and groups of heterogeneous body size (with three individuals of different length). Behavioral tests were performed at six time points, namely $12,24,36,48$, 60 and 72 hours after hatching (HAH), with 10 replications per treatment and observation point, totalizing 120 groups.

The larvae were collected from the incubator and transferred (with the aid of $3 \mathrm{ml}$ plastic pipettes) to a round glass container ( $2 \mathrm{~cm}$ wide $x 1.5 \mathrm{~cm}$ high) containing $3 \mathrm{~mL}$ of water. The animal density was similar to that in the incubator (1 larva $\mathrm{mL}^{-1}$ ). We used a separator with a scale grid placed on the bottom of the incubator in order to estimate the size of the larvae and select them visually for each treatment.

The larvae were acclimated for $10 \mathrm{~min}$, and their behavior was video-recorded (Handycam Sony DCR-SX63) over the next $20 \mathrm{~min}$ for each replication. After the recordings, the specimens (30 larvae per treatment and time point) were sacrificed by anesthetic overdose (eugenol; $5 \mu \mathrm{L}^{-1}$ ) and fixed in $4 \%$ formalin for posterior measurement of the total length (in $\mathrm{mm}$; conducted with an ichthyometer made from a microscope slide and graph paper). Analysis of the coefficients of variation of total length allowed the evaluation 
of size homogeneity within each group (following Leonardo et al. 2008).

Aggressive behaviour was quantified based on an ethogram consisting of the following units (following Souza et al. 2014): (a) Approach: an animal swims toward the opponent, without threat or physical contact; (b) Attack: the aggressor strikes with the head of the opponent's body; (c) Flight: the attacked or chased larva moves away from the contest place; (d) Threat: the larva approaches the opponent, preparing for attack, but its opponent moves away.

The total contest was considered to be the sum of all aggressive units, which excluded flight (e.g., Souza et al. 2014; Lopes et al. 2018). Each animal was categorized based on a dominance index (DI) that corresponded to the number of attacks initiated by each animal relative to the total number of attacks within the group (Carvalho and Gonçalves-de-Freitas 2011). The DI ranged from 0 to 1.0 , and the three animals in each group were classified as: A - larva with the higher DI, thus higher aggression level; $\mathrm{B}$ - larva with the intermediate DI, thus intermediate aggression level; and C - larva with the lower DI, thus lower aggression level. We quantified the aggressive interaction exhibited by each animal (A, B and C) in the group.

\section{Experiment II}

A second experiment was performed at the Santo Antonio Farm, in Rio Preto da Eva, Amazonas (AM), Brazil $\left(02^{\circ} 41^{\prime} 55^{\prime \prime} \mathrm{S} ; 59^{\circ} 42^{\prime} 3\right.$ 'W), in order to evaluate the effect of size heterogeneity on the mortality rate of matrinxâ larvae. The larvae were produced via artificial propagation according to the method described in Experiment I and based on Romagosa $e t$ al. (2001). Fertilized eggs were deposited in a $35 \mathrm{~L}$ cylindrical incubator $\left(1 \mathrm{~g} \mathrm{eggs}^{-1}\right)$ with constant water renewal at $28^{\circ} \mathrm{C}$. Larvae were separated into two treatments: homogeneous body size (individuals of similar length), and heterogeneous body size (individuals of different length). Mortality rates were recorded at six time points: 12, 24, 36, 48, 60 and 72 $\mathrm{HAH}$, with five replications per treatment and observation point, totalizing 60 groups.

At each time point we transfered larvae from the incubator to containers (polypropylene trays) containing $1 \mathrm{~L}$ of water at a density of 1 larva $\mathrm{mL}^{-1}$, which was similar to the incubator density. We used a separator to select larvae (as described for Experiment I). The larvae were left in each container for 2 hours, a period sufficiently long to elicit the display of the aggressive repertoire that can result in mortality. After the 2 hours we counted all larvae still alive. The mortality rate was calculated as the subtraction of the final number of live larvae from the initial total number of larvae in each container at each time point.

\section{Data analysis}

Coefficients of variation of total length were compared between treatments using an independent t-test. Data were tested for normality using the Shapiro-Wilk test. According to the distribution and variance of the data, the frequency of aggressive interactions (Experiment I) was compared between treatments using the Mann-Whitney test and between observation time points using the Kruskal-Wallis test. In Experiment II, the mortality rates were compared between treatments and over time using two-way analysis of variance (ANOVA). The least significant difference (LSD) test was used for multiple comparisons at $\alpha \leq 0.05$. All analyses were based on Zar (1999) and were performed using the STATISTICA 7.0 software.

\section{RESULTS}

The coefficient of variation of total length of larvae within groups was significantly lower in the homogeneous size than in the heterogenous size treatment at each time point in Experiment $\mathrm{I}(\mathrm{t}$-test, $\mathrm{t}>-6.84, \mathrm{P}<0.002$; Table 1$)$ and Experiment II ( $\mathrm{t}$-test, $\mathrm{t}>-5.92, \mathrm{P}<0.01$; Table 2$)$.

The frequency of aggressive behaviour events of the most aggressive larva (individual A) did not differ significantly between the treatments (Mann-Whitney: $\mathrm{U}=35.5, \mathrm{p}=0.27$;

Table 1. Body size data of Brycon amazonicus larvae used in Experiment I. Total length and coefficient of variation (CV) in total length among experimental groups in two treatments (homogeneous body size, HOM, and heterogeneous body size, $\mathrm{HET}$ ) at different time points of larval development (in hours after hatching, $\mathrm{HAH}$ ) Values are the mean \pm SD of 10 replicates. Asterisks indicate statistically significant differences between treatments $(L S D, p<0.03)$

\begin{tabular}{lccccc}
\hline \multirow{2}{*}{$\begin{array}{l}\text { Time point } \\
\text { (HAH) }\end{array}$} & \multicolumn{2}{c}{ Total length $(\mathrm{mm})$} & & \multicolumn{2}{c}{$\mathrm{CV}$} \\
\cline { 2 - 3 } \cline { 5 - 6 } & HOM & HET & & HOM & HET \\
\hline 12 & $3.7 \pm 0.3$ & $3.7 \pm 0.6$ & & $3.4 \pm 1.1$ & $10.9 \pm 1.5^{*}$ \\
24 & $6.0 \pm 0.1$ & $6.2 \pm 0.4$ & & $0.6 \pm 0.1$ & $5.9 \pm 1.8^{*}$ \\
36 & $7.0 \pm 0.1$ & $7.1 \pm 0.4$ & & $0.6 \pm 0.1$ & $5.9 \pm 1.5^{*}$ \\
48 & $7.0 \pm 0.1$ & $7.4 \pm 0.4$ & & $0.7 \pm 0.1$ & $4.9 \pm 0.9^{*}$ \\
60 & $7.5 \pm 0.3$ & $7.5 \pm 0.4$ & & $3.8 \pm 0.3$ & $5.5 \pm 0.6^{*}$ \\
72 & $7.5 \pm 0.1$ & $7.5 \pm 0.4$ & & $1.9 \pm 0.3$ & $5.8 \pm 0.2^{*}$ \\
\hline
\end{tabular}

Table 2. Body size data of Brycon amazonicus larvae used in Experiment II. Total length and coefficient of variation (CV) in total length among experimental groups in two treatments (homogeneous body size, HOM, and heterogeneous body size, $\mathrm{HET}$ ) at different time points of larval development (in hours after hatching, $\mathrm{HAH}$ ). Values are the mean \pm SD of 10 replicates. Asterisks indicate statistically significant differences between treatments (LSD, $\mathrm{p}<0.03)$

\begin{tabular}{lccccc}
\hline \multirow{2}{*}{$\begin{array}{l}\text { Time point } \\
\text { (HAH) }\end{array}$} & \multicolumn{2}{c}{ Total length $(\mathrm{mm})$} & & \multicolumn{2}{c}{ CV } \\
\cline { 2 - 3 } \cline { 5 - 6 } & HOM & HET & & HOM & HET \\
\hline 12 & $3.8 \pm 0.4$ & $3.7 \pm 0.6$ & & $3.5 \pm 1.0$ & $10.8 \pm 1.5^{*}$ \\
24 & $6.0 \pm 0.1$ & $6.2 \pm 0.3$ & & $0.6 \pm 0.2$ & $5.9 \pm 1.4^{*}$ \\
36 & $7.0 \pm 0.1$ & $7.0 \pm 0.4$ & & $0.6 \pm 0.1$ & $5.8 \pm 1.9^{*}$ \\
48 & $7.1 \pm 0.1$ & $7.4 \pm 0.4$ & & $0.7 \pm 0.1$ & $4.9 \pm 0.9^{*}$ \\
60 & $7.4 \pm 0.3$ & $7.5 \pm 0.4$ & & $3.8 \pm 0.2$ & $5.4 \pm 0.6^{*}$ \\
72 & $7.5 \pm 0.2$ & $7.5 \pm 0.4$ & & $1.9 \pm 0.3$ & $5.8 \pm 0.2^{*}$ \\
\hline
\end{tabular}


Figure 1). The frequency of aggressive behaviour of larvae with intermediate and least aggressiveness (individuals B and $\mathrm{C}$, respectively) was significantly higher in the homogeneous size treatment at all time points [larvae B: approach (MannWhitney: $\mathrm{U}=4.61, \mathrm{p}=0.03$ ) and total contest (MannWhitney: $\mathrm{U}=4.40, \mathrm{p}=0.04)$; Figure 2]; [larvae C: attack (Mann-Whitney: $\mathrm{U}=3.5, \mathrm{p}=0.04$ ) and total contest (MannWhitney: $U=3.65, p=0.04)$; Figure 3]. The frequency of aggressive interactions was higher at 12 and $72 \mathrm{HAH}$ than at 36 and $60 \mathrm{HAH}$ in both treatments (Kruskal-Wallis: $\chi^{2}<$ $52.80, \mathrm{p}<0.002$; Figures 1-3).

There was no significant interaction between time point and size heterogeneity regarding the mortality rate in Experiment II (two-way ANOVA: $\mathrm{F}=1.23, \mathrm{p}=0.31$ ). Mortality increased significantly over time $(p=0.001$; Figure 4 ), with a higher total mortality (mean of the six time points) in the homogeneous size treatment $(\mathrm{p}=0.03$; Figure 4$)$.

\section{DISCUSSION}

The significantly higher coefficient of variation in larvae groups of the heterogeneous size treatment showed that our method for larvae selection was appropriately performed, according to Santos Jr. et al. (1996).

As is already known, the intensity of aggressive interaction in fish is related to variation in size within the cohort (e.g.,
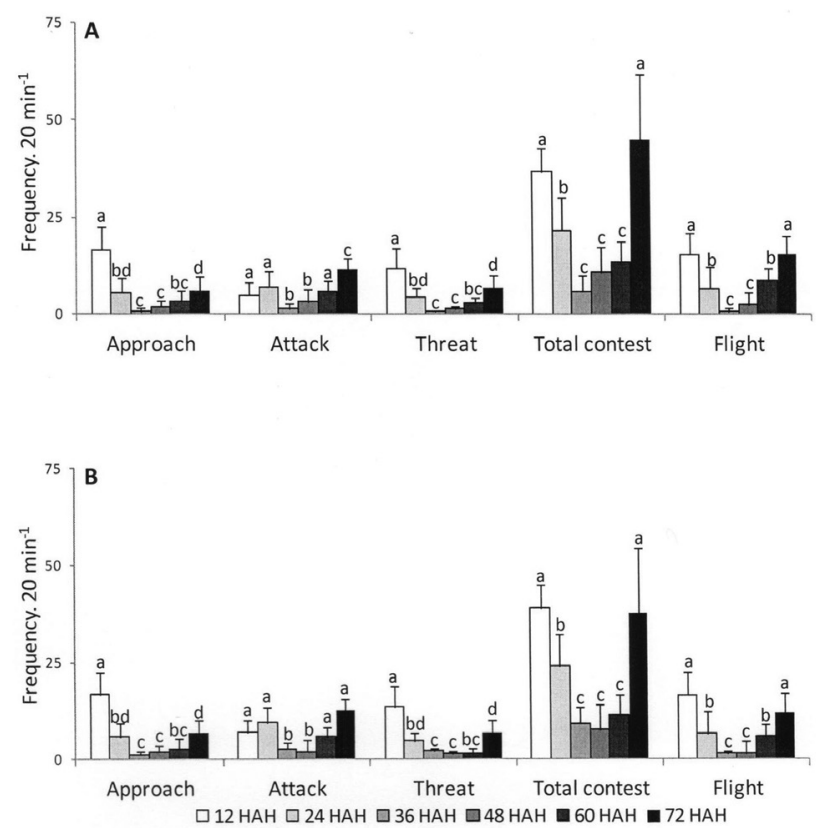

Figure 1. Number of aggressive interactions by the A larva (higher aggressive level in each replicate) at each time point in the homogeneous size (A) and heterogeneous size (B) treatments. Values are the mean \pm SD of 10 replicates. $\mathrm{HAH}$ $=$ hours after hatching. Different letters indicate statistically significant differences among time points (Kruskal-Wallis, $X^{2}<52.80, p<0.002$ ). Asterisks indicate statistically significant differences between treatments $(p<0.05)$.
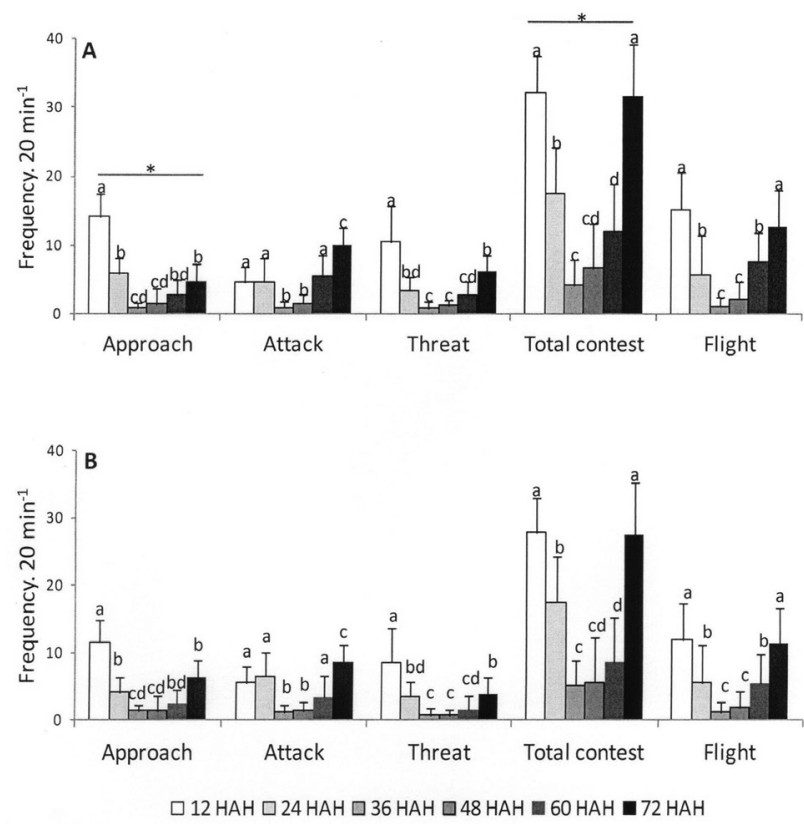

Figure 2. Number of aggressive interactions by the B larva (intermediate aggressive level in each replicate) at each time point in the homogeneous size (A) and heterogeneous size (B) treatments. Values are the mean \pm SD of 10 replicates. $\mathrm{HAH}=$ hours after hatching. Different letters indicate statistically significant differences among time points (Kruskal-Wallis, $X^{2}<52.80, p<0.002$ ). Asterisks indicate statistically significant differences between treatments $(p<0.05)$.
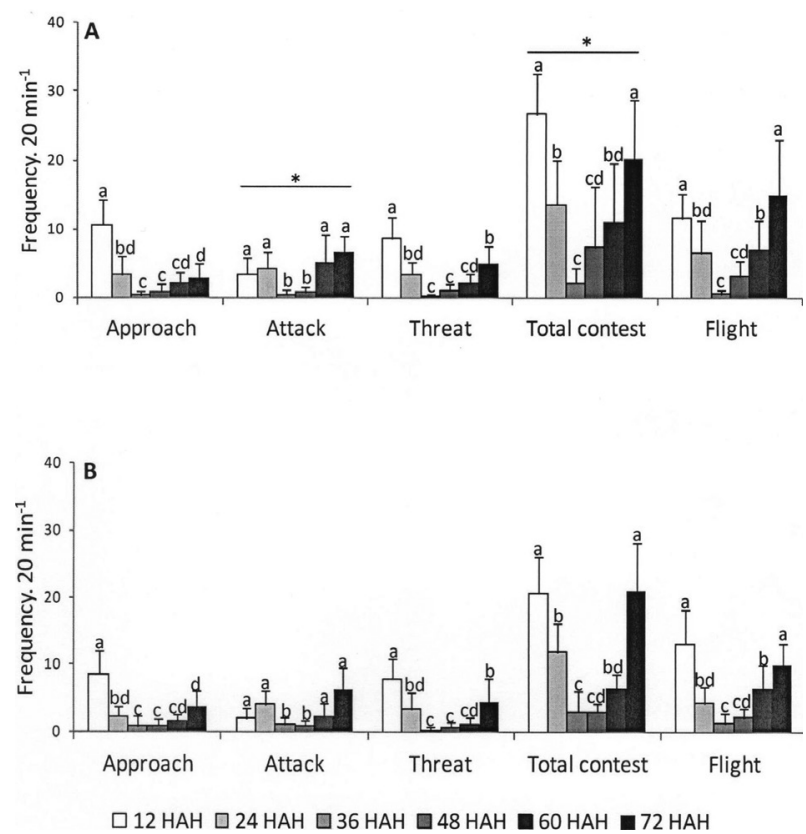

Figure 3. Number of aggressive interactions by the $C$ larva (lower aggressive level in each replicate) at each time point in the homogeneous size (A) and heterogeneous size (B) treatments. Values are the mean \pm SD of 10 replicates. HAH $=$ hours after hatching. Different letters indicate statistically significant differences among time points (Kruskal-Wallis, $X^{2}<52.80, p<0.002$ ). Asterisks indicate statistically significant differences between treatments $(p<0.05)$. 


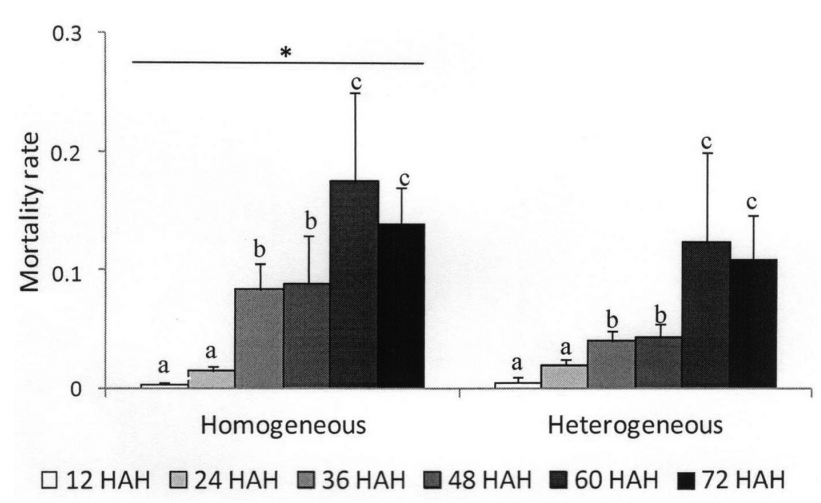

Figure 4. Mortality rates of Brycon amazonicus larvae in homogeneous sized and heterogeneous sized groups at different time points of larval development. Values are the mean \pm SD of 5 replicates. $\mathrm{HAH}=$ hours after hatching. Different letters indicate statistically significant differences among time points (LSD, $p<0.001)$. Asterisks indicate statistically significant differences between treatments $(p=0.03)$.

Beeching 1992), and consequently affects the mortality rate. We confirmed that aggressiveness varied among larval development stages, and that body size heterogeneity influences agonistic interactions in less aggressive larvae of B. amazonicus.

In general, aggressive fish species that compete intensively for food exhibit faster larval development, thereby increasing food capture and survival success. For example, skeletal ossification of pacu (Piaractus mesopotamicus) larvae is complete when larvae reach 40 post-hatching days (DPH) (Portella et al. 2014), whereas in Brycon orbignyanus ossification is complete in larvae with 7 DPH (Maciel et al. 2010). Thus, the fast larval development in B. amazonicus (e.g., Neumann 2008; Nakauth et al. 2016) may modulate the display of aggressive behavior in this species.

Matrinxã larvae hatch 10.5 hours after fertilization, exhibiting erratic vertical swimming characterized by upward movement, followed by constant sinking in the water column (Nakauth et al. 2016). The oral cavity opens at $18 \mathrm{HAH}$, the mouth of larvae is completely opened, with sharp teeth and start of cannibalism at 30$34 \mathrm{HAH}, 40-70 \%$ of the yolk sac is apparently absorbed at $40 \mathrm{HAH}$, and more than $90 \%$ of the calf is absorbed at $60 \mathrm{HAH}$, with swim bladder inflation and horizontal swimming, suggesting greater control of swimming activity (Nakauth et al. 2016). The early stages of development affected individual aggression in both our treatments, with highest rates of aggressive behavior observed at 12 $\mathrm{HAH}$. Thus, aggressive behavior started before the yolk sac was completely absorbed, as soon as opening of the mouth and oral teeth were completely developed. A similar behavior was observed in Brycon moorei (Baras et al. 2000), implying that aggressiveness may be genetically regulated or related to environmental parameters (e.g., Dou et al. 2000;
Yang et al. 2015). The frequency of aggressive interaction was lower at 36 and $48 \mathrm{HAH}$, suggesting that reduced locomotor activity can reduce the likelihood of encounters, thus reducing social interactions between group members. Indeed, Souza et al. (2014) observed reduced locomotor activity in B. amazonicus at times when aggressive behavior was less frequent. The greater aggressiveness observed at $72 \mathrm{HAH}$ can be related to the search for protection of a suitable habitat, foraging, predator avoidance, or territory defense, as $B$. amazonicus displays territorial behavior (Ferraz and Gomes 2009).

The greater aggressiveness in early larval development (12 and $24 \mathrm{HAH}$ ) may have lead to increased mortality starting at $36 \mathrm{HAH}$, when Bernardino et al. (1993) also observed lower survival rates. This result is expected, as aggressive behavior at the early larval stage results in bites, injuries and stress, which can facilitate the action of pathogens and thus increase mortality (Katavic et al. 1989; Huntingford et al. 2006). The increase in mortality observed from $60 \mathrm{HAH}$ may be related to the higher frequency of aggressive interactions observed at these time points.

Some studies have emphasized that size heterogeneity increases aggressive interactions in predatory species (Baras 1998; Kestemont et al. 2003; Moran 2007), while others suggest that the homogeneous size distribution in groups of social animals can increase aggressive interactions, as similarly sized animals have the same fighting ability, consequently increasing social stress (Beeching 1992). The size heterogeneity of a group influences the type of aggression displayed by hybrid juvenile catfish, Silurus meridionalis-asotus (Yang et al. 2015). Our results showed that size heterogeneity in a group reduces the frequency of aggressive interactions in matrinxâ, especially in less aggressive larvae.

Comparing the display of aggressive behavior and the mortality rate across time points and in both treatments, higher mortality was observed at 60 and $72 \mathrm{HAH}$, which may be explained by the injuries caused by aggressive interactions in the initial periods of development. Overall mortality was higher in the homogeneous size treatment, which may be attributed to the higher energy expenditure and larger number of physical injuries resulting from aggressive interactions between animals with similar fighting skills.

\section{CONCLUSIONS}

Our two experiments allowed us to relate the display of aggressive behavior and survival with heterogeneity of size within a cohort of matrinxã, Brycon amazonicus larvae. Aggressiveness was higher among individuals in homogeneous sized groups, which resulted in higher mortality, possibly due to similarly sized animals having similar fighting ability. 
Our study highlights the importance of understanding the social behavior of $B$. amazonicus in order to propose effective measures of manipulation of biotic and abiotic factors to reduce aggressiveness and mortality in the larval stages of matrinxã. Future studies should be developed in a more complex context of larval size distributions that can be directly applied in matrinxã farming.

\section{ACKNOWLEDGMENTS}

This study was funded by Fundação de Amparo à Pesquisa do Estado do Amazonas (FAPEAM), project no. 015/2014 - PAPAC.

\section{REFERENCES}

Baras, E. 1998. Biological bases of cannibalism in fish. Cahiers d'Ethologie, 18: 53-98.

Baras, E.; Ndao, M.; Maxi, M.Y.J.; Jeandrain, D.; Thomé, J.P.; Vanadewalle, P.; Mélard, C. 2000. Sibling cannibalism in dorada under experimental conditions. I. Ontogeny, dynamics, bioenergetics of cannibalism and prey size selective. Journal of Fish Biology, 57: 1001-1020.

Beeching, S.C. 1992. Visual assessment of relative body size in a cichlid fish, the oscar, Astronotus ocellatus. Ethology, 90: 177-186.

Bernardino, G.; Senhorini, J.A.; Fontes, N.A.; Bock, C.L.; Mendonça, J.O.J. 1993. Propagação artificial do matrinchá, Brycon cephalus (Günther, 1869), (Teleostei, Characidae). Boletim Técnico CEPTA, 6: 1-9.

Carvalho, T.B.; Gonçalves-de-Freitas, E. 2011. Social Stability Related to Sex Group Composition in the Cichlid Nile Tilapia. Dynamic Biochemistry, Process Biotechnology and Molecular Biology, 5: 88-91.

Dou, S.; Seikai, T.; Tsukamoto, K. 2000. Cannibalism in Japanese flounder juveniles, Paralichthys olivaceus, reared under controlled conditions. Aquaculture, 182: 149-159.

Ferraz, F.B.; Gomes, L.C. 2009. Social relationship as inducer of immunological and stress responses in matrinxã (Brycon amazonicus). Comparative Biochemistry and Physiology, 153: 293-296.

Fernandes, M.O.; Volpato, G.L. 1993. Heterogeneous growth in the Nile tilapia: social stress and carbohydrate metabolism. Physiology and Behavior, 54: 319-323.

Gomes, L.C.; Urbinati, E.C. 2010. Matrinxã (Brycon amazonicus). In: Baldisserotto, B.; Gomes, L.C. (Ed.). Espécies Nativas para Piscicultura no Brasileira. Editora da UFSM, Santa Maria, Rio Grande do Sul, p.149-174.

Huntingford, F.; Turner A. 1987. Animal conflict. Chapman and Hall, New York, 448p.

Huntingford, F.A.; Adams, C.; Braithwaite, V.A.; Kadri, S.; Pottinger, T.G.; Sandoe, P.; Turnbull, J.F. 2006. Current issues in fish welfare. Journal Fish Biology, 68: 332-372.

Katavic, I.; Jug-Dujakovic, J.; Glamuzina, B. 1989. Cannibalism as a factor affecting the survival of intensively cultured sea bass (Dicentrarchus labrax) fingerlings. Aquaculture, 77: 135-143.
Kestemont P.; Jourdan S.; Houbart M.; Mélard C.; Paspatis M.; Fontaine P.; Cuvier A.; Kentouri, M.; Baras, E. 2003. Size heterogeneity, cannibalism and competition in culture predatory fish larvae: biotic and abiotic influences. Aquaculture, 227: 333-356.

Leonardo, A.F.G.; Hoshiba, M.A.; Senhorini, J.A.; Urbinati E. C. 2008. Canibalismo em larvas de matrinxã, Brycon cephalus, após imersão dos ovos à diferentes concentraçôes de triiodotironina $\left(\mathrm{T}_{3}\right)$. Boletim do Instituto de Pesca, 34: 231-239.

Lopes, A.C.; Villacorta-Correa, M.A.; Carvalho, T.B. 2018. Lower light intensity reduces larval aggression in matrinxã, Brycon amazonicus. Behavioural Processes, 151: 62-66.

Maciel, C.M.R.R.; Lanna, E.A.T.; Maciel Jr., A.; Donzele, J.L.; Neves, C.A.; Menin E. 2010. Morphological and behavioral development of the piracanjuba larvae. Revista Brasileira de Zootecnia, 39: 961-970.

Moran, D. 2007. Size heterogeneity, growth potential and aggression in juvenile yellow tail kingfish (Seriola lalandi Valenciennes). Aquaculture Research, 38: 1254-1264.

Nakauth, A.C.S.S.; Villacorta-Correa, M.A.; Figueiredo, M.R.; Bernardino, G.; França, J.M. 2016. Embryonic and larval development of Brycon amazonicus (Spix \& Agassiz, 1829). Brazilian Journal of Biology, 76: 109-116.

Neumann, E. 2008. Desenvolvimento inicial da jatuarana, Brycon amazonicus (Teleostei, Characidae). Doctoral thesis, Centro de Aquicultura da Universidade Estadual Paulista, Jaboticabal, São Paulo. 125p.

Portella, M.C.; Jomori, R.K.; Leitão, N.J.; Menossi, O.C.C.; Freitas, T.M.; Kojima, J.T.; Lopes, T.S.; Clavijo-Ayala, J.A.; Carneiro, D.J. 2014. Larval development of indigenous South American freshwater fish species, with particular reference to pacu (Piaractus mesopotamicus): A review. Aquaculture, 432: 402-417.

Romagosa E.; Narahara M.Y.; Borella M.I.; Fenerich-Verani N. 2001. Seleção e caracterização de fêmeas de matrinxã, Brycon cephalus, induzidas a reprodução. Boletim do Instituto de Pesca, 27: 113-121.

Santos, Jr. S.; Ramos. S.M.; Ramos, R.O. 1996. Influência do tamanho inicial das larvas de pacu, Piaractus mesopotamicus (Holmberg, 1887) no crescimento e sobrevivência. Boletim Técnico CEPTA, 9: 1-10.

Sakakura, Y.; Tsukamoto, K. 1998. Effects of density, starvation and size difference on aggressive behaviour in juvenile yellowtails (Seriola quinqueradiata). Journal of Applied Ichthyology, 14: 9-13.

Senhorini, J. A.; Mantelatto, F. L. M. and Casanova, S. M. C. 1998. Growth and survival of larvae of the Amazon species "matrinxâ", Brycon cephalus (Pisces, Characidae), in larviculture ponds. Boletim Técnico do CEPTA, 11: 13-28.

Senhorini, J.A.; Gaspar, L.A.; Fransozo, A. 2002. Crescimento, sobrevivência e preferência alimentar de larvas de matrinxâ (Brycon cephalus) e de piracanjuba (Brycon orbignyanus) em viveiros. Boletim Técnico do CEPTA, 15: 9-21.

Souza, E.C.M.; Silva, J.P.; Villacorta-Correa, M.A.; Carvalho. T.B. 2014. Aggressiveness and locomotion activity related to hatching time in matrinxã, Brycon amazonicus (Spix and Agassiz, 1829). Applied Animal Behaviour Science, 157: 146-151. 
ACTA

AMAZONICA

Yang, S.; Yang, K; Liu, C.; Sun, J.; Zhang, F.; Zhang, X.; Song, Z. 2015. To what extent is cannibalism genetically controlled in fish? A case study in juvenile hybrid catfish Silurus meridionalis-asotus and the progenitors. Aquaculture, 437: 208-214.

Zaniboni-Filho, E.; Reynalte-Tataje, D.; Weingartner, M. 2006. Potencialidad del género Brycon en la piscicultura brasileña. Revista Colombiana Ciências Pecuárias, 19: 233-240.

Zar, J. 1999. Biostatistical analyses. Printice Hall, New Jersey, 663p.

RECEIVED: 06/03/2018

ACCEPTED: 14/08/2018

ASSOCIATE EDITOR: Rodrigo do Valle 